\title{
Statistical Analysis on Relationship between Muhammadiyah Growths in 1912 - 1964 and its Heritage
}

\author{
Shubhi Mahmashony Harimurti \\ Pharmacy Department, Faculty of Mathematic and Natural Sciences, \\ Universitas Islam Indonesia \\ shubhi.mahmashony@uii.ac.id
}

Article history:

Received April 29, 2017

Revised July 17, 2017

Accepted August 05, 2017

Keywords:

Statistic

Member

Heritage

Muhammadiyah

\begin{abstract}
The phenomenal movement of Muhammadiyah with their growing assets is interesting to be studied in archaeological perspective. This research will focus on a period between 1912 - 1964 when the significant growth of Muhammadiyah as an organization took place. Spatially, this research will concentrate in three sub-districts of Gondomanan, Ngampilan, and Wirobrajan. This research is addressed to answer the question whether there is significant relationship between the growth of Muhammadiyah and the quantity of material assets owned by this organization during $1912-1964$. The research objective is demonstrating the relationship between the growth of Muhammadiyah and its material heritage. Therefore, this research tries to demonstrate correlation between the growth of Muhammadiyah and the material heritage owned by the organization. The growth of Muhammadiyah is represented in the number of its membership and the material culture is indicated by the quantity of its sites. The correlation is measured by using statistical method. The statistical calculation shows there is a strong relationship between the quantity of Muhammadiyah sites and the growth of the organization. This is the result of many 'behavioral' aspects of the Muhammadiyah movement especially in socialreligious, ijtihad, education, regeneration, and administrative sectors. From 1912 - 1964, the material assets of Muhammadiyah had undergone transformation in different ways.
\end{abstract}

\section{Introduction}

In this study demonstrated that there is a relationship between the performance of the organization of Muhammadiyah with archaeological remains, especially in the area of the core of the organization's progress in the three districts of Yogyakarta. That relationship will be analyzed among others in statistics. Statistical analysis will begin with the structuring and presentation of data in the form of histograms, pie-chart, or polygons. Measures of central tendency which includes the mean, median, and modus are also included. All of them had been a descriptive statistic. The population in this study also determined. The parameters are also described in this section. Population, parameters, and the correlation is included inductive and parametric statistical analysis.

This study used two variables: the extent of the archaeological remains and the Muhammadiyah development as indicated by the number of official members. Both must be proven to have a linear relationship between each other (correlation). The analysis process using computer software called SPSS 15.

\section{Data Description}

From the description of the heritage of Muhammadiyah results presented previously obtained data on the area of the location or site where existing buildings. If the data are presented in the table, then the result can be seen as in Table 1 below. 
Table 1. Area of Muhammadiyah Heritage

\begin{tabular}{ccc}
\hline No & Building Name & Width $\left(\mathbf{m}^{\mathbf{2}}\right)$ \\
\hline 1 & Gedoeng Muhammadiyah & 867 \\
\hline 2 & Ahmad Dahlan Mosque & 81,4 \\
\hline 3 & ASRI Field & 5.000 \\
\hline 4 & Madrasah Mu'allimaat Muhammadiyah & 3.000 \\
\hline 5 & Madrasah Mu'allimin Muhammadiyah & 9.125 \\
\hline 6 & 'Aisyiyah Mosque & 399 \\
\hline 7 & Muhammadiyah Kauman Elementary School & 1.177 \\
\hline 8 & Muhammadiyah Notoprajan Elementary School & 80 \\
\hline 9 & Muhammadiyah Junior High School 1 & 2.350 \\
\hline 10 & 81,4 & 2.000 \\
\hline
\end{tabular}

Table 2. Population of Muhammadiyah Members

\begin{tabular}{ccc}
\hline No. & Year & Members (Person) \\
\hline 1 & 1912 & 9 \\
\hline 2 & 1916 & 114 \\
\hline 3 & 1920 & 261 \\
\hline 4 & 1924 & 261 \\
\hline 5 & 1928 & 261 \\
\hline 6 & 1932 & 261 \\
\hline 7 & 1936 & 261 \\
\hline 8 & 1940 & 976 \\
\hline 9 & 1944 & 1.453 \\
\hline 10 & 1948 & 1.790 \\
\hline 11 & 1952 & 2.171 \\
\hline 12 & 1956 & 2.468 \\
\hline 13 & 1960 & 3.004
\end{tabular}

The following are heritage data that is served in some statistical appearance. 


\subsection{Histogram}

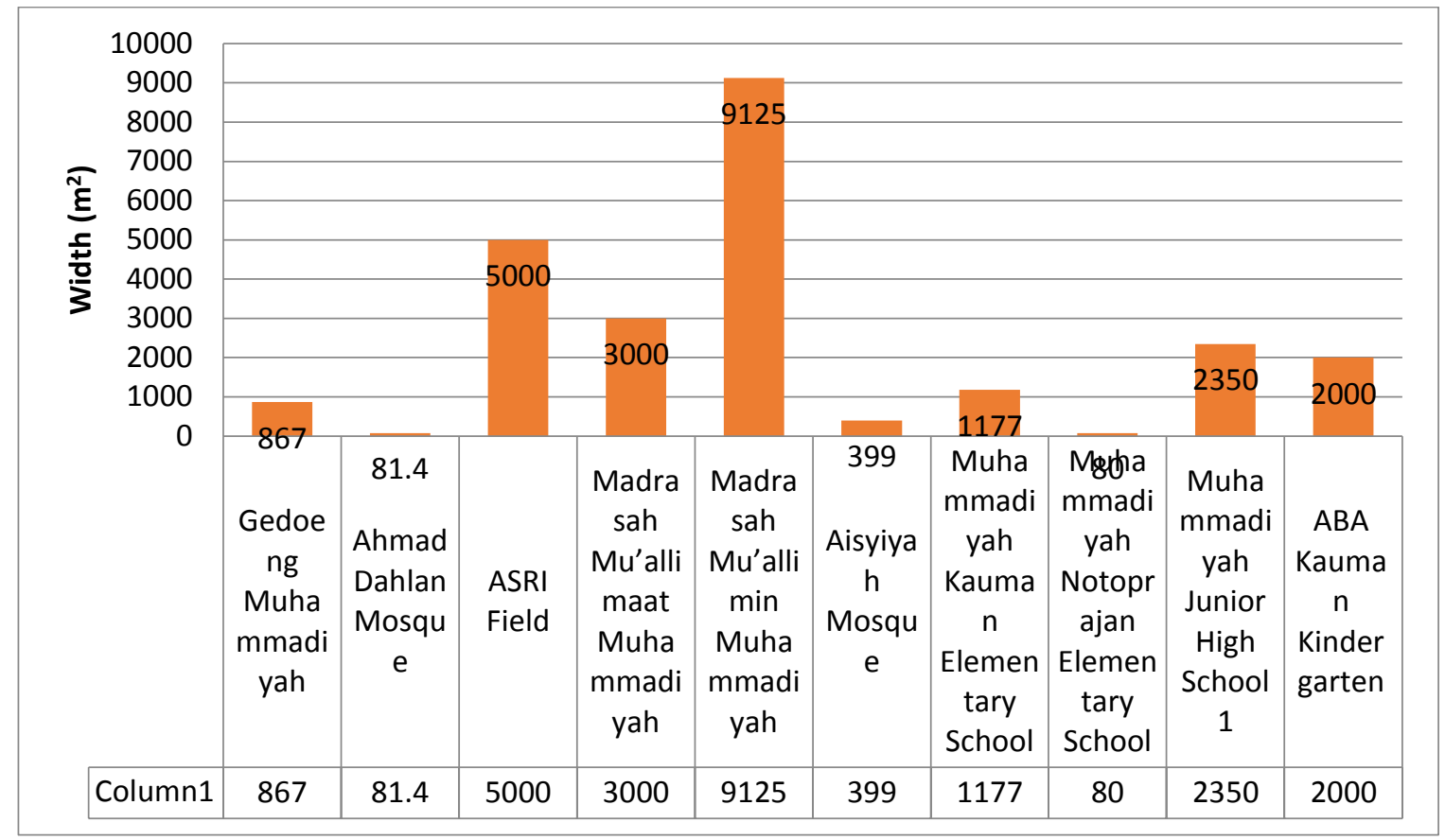

Fig. 1.Histogram of the Area of Heritage of Muhammadiyah

\subsection{Concentrate Measurement}

Measures of central tendency include mean, median, modus, size diversity, and standard deviation. Mean values mean the average of the overall sample. Median means that the value of the middle of the line sample. Modus means that the most frequently arise data. Size of diversity means that the relative position of each observation data against the average cluster data. Standard deviation means the withdrawal of the root of the population variance

Table 3. Size Concentration

\section{Statistics}

\begin{tabular}{|l|l|l|}
\hline & Name & Large \\
\hline $\mathrm{N}$ & 10 & 10 \\
Mean & & 2407,940 \\
Median & & 1588,500 \\
Mode & & $80,0(\mathrm{a})$ \\
Standard Deviation & & 2811,0026 \\
Variance & & 7901735,503 \\
Sum & & 240179,4 \\
\hline
\end{tabular}

A Multiple mode exists. The smallest value is shown.

\section{Parametric Statistics}

\subsection{Population and Parameters}

Parametric statistics is a science in which to consider the type of distribution or data distribution. Both data is spread normally or not normally. An example is the T test and Pearson correlation. All formulas that apply parametric statistics are derived from a mathematical formula. It is required to have a normality of data, so there is no bias and false targets on the parameters (Walpole, 1997, 428). The reason is because the use of parametric statistics can be used to make conclusions based on the relationship between one variable to another.

In this case, the definition of the population is a whole range of data which is the object of observation or it could also be said that data are all the things that made the object of research (Santoso 2009, 3). The population in this study is the whole heritage object of the Gondomanan District, Ngampilan District and Wirobrajan District in Yogyakarta owned by Muhammadiyah. 
Parameter is an arbitrary measurement value that delineates the population. Samuel Kotz (2005, 5928) said that parameter means a condition restricting possible action.

The parameters are the data obtained from the PDM Yogyakarta which showed that the heritage objects coming from the three districts mentioned above are in 10 units. That means the population parameter comes to 10 units.

\subsection{Correlation}

The meaning of correlation is a statistical analysis that determine the relationship between two variables (bivariate correlation) or more (multivariate correlation) (Hartono, 2010, 51). Another opinion said that the correlation is a measure that indicates how well the data have a relationship one other (Shennan 1988, 119). Data must be in the shape of variable numbers. One of the benefits of data processing by correlation method is it can be represented in the form of a diagram. The first variable in this research is the development of Muhammadiyah, while the second variable is the development of the quantity of Muhammadiyah heritage. Muhammadiyah development is the development of its members. Muhammadiyah members are still counted from the beginning of the record until now although there are members who already died. Variable 1 is called the independent variable that gives influence.

Next is the dependent variable or affected one.

Table 4. Development of Total Area of Muhammadiyah Heritage in Three Districts.

\begin{tabular}{|c|c|}
\hline Year & Large \\
\hline 1912 & 81,4 \\
1916 & 81,4 \\
1920 & 81,4 \\
1924 & 560,4 \\
1928 & 560,4 \\
1932 & 17685,4 \\
1936 & 20035,4 \\
1940 & 20035,4 \\
1944 & 20902,4 \\
1948 & 20902,4 \\
1952 & 20902,4 \\
1956 & 20902,4 \\
1960 & 20902,4 \\
1964 & 24079,4 \\
\hline
\end{tabular}




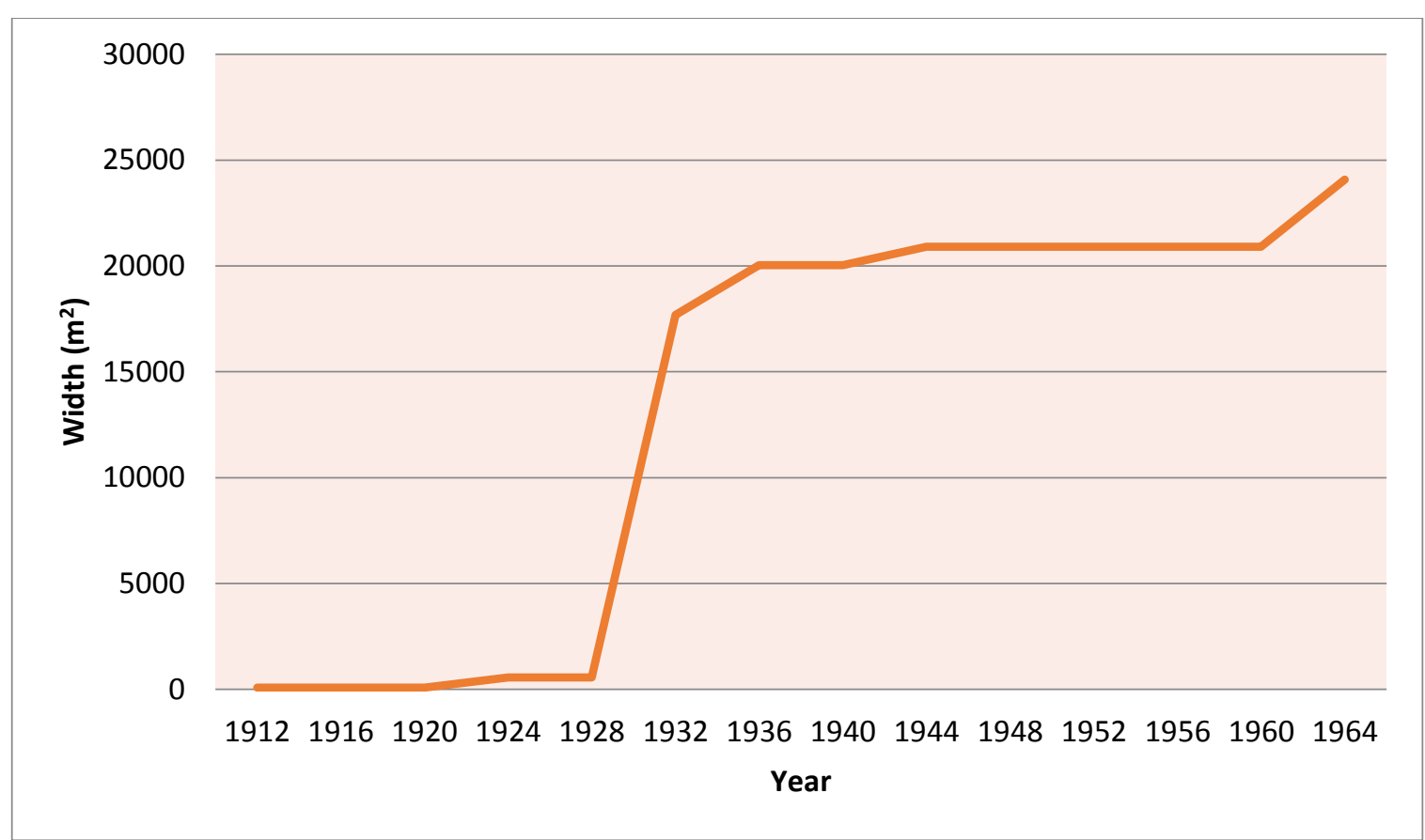

Fig. 2.Line Diagram of Total Area of Muhammadiyah in Three Districts.

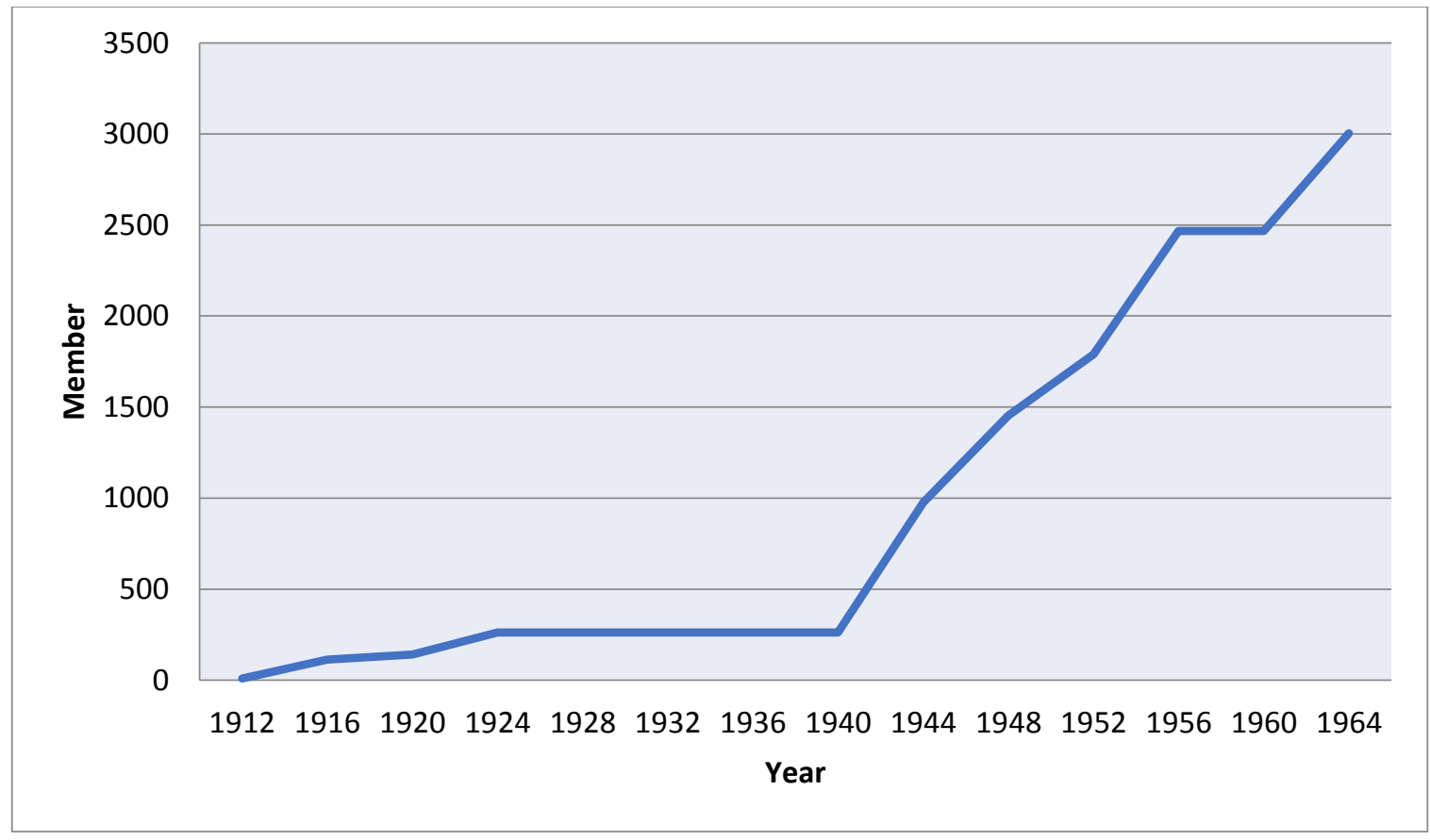

Fig. 3.Line Diagram of Total Member of Muhammadiyah in Three Districts. 


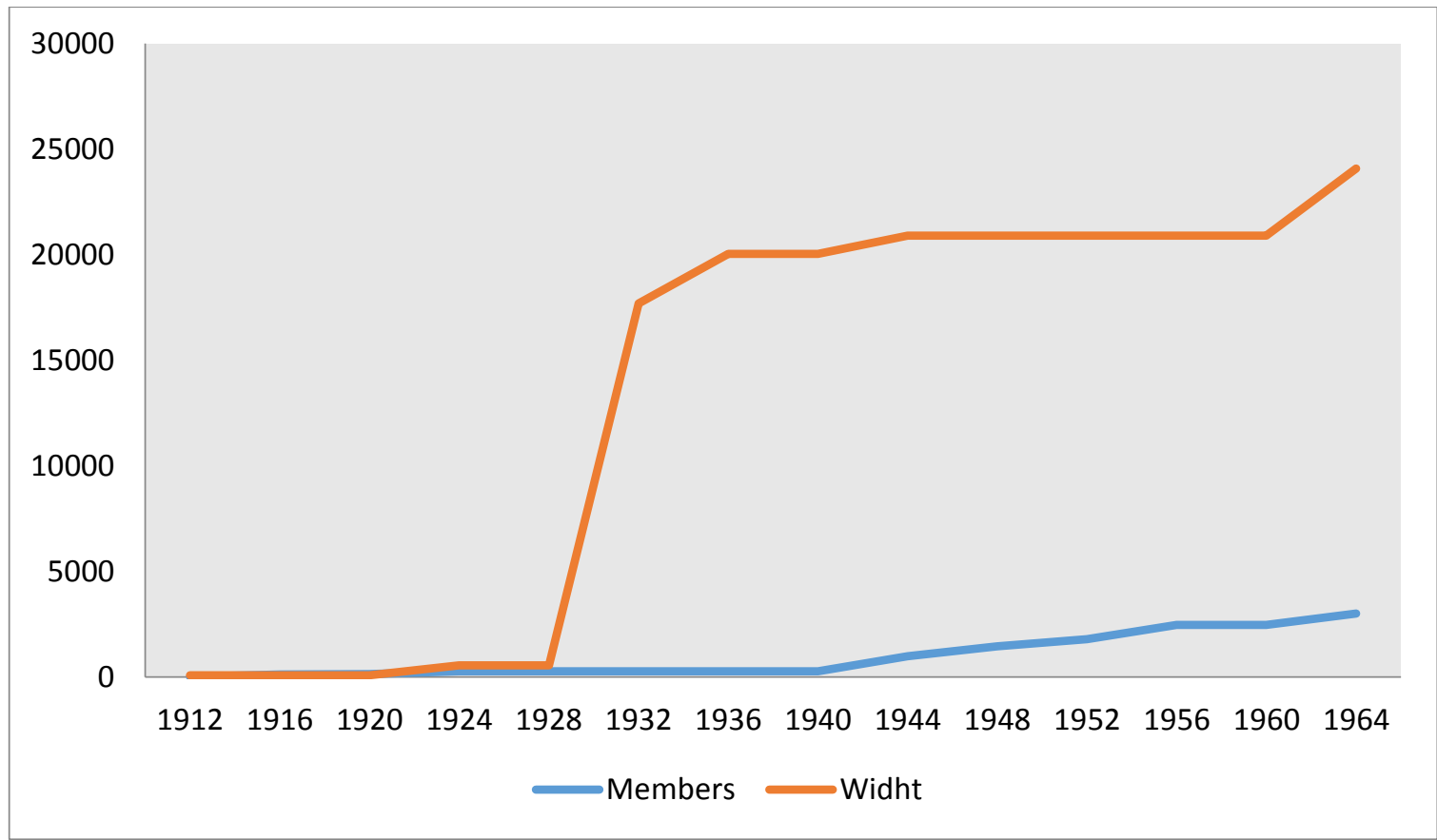

Fig. 4.Line Diagram of Total Members of Muhammadiyah and Development of Total Area of Muhammadiyah Heritage in Three Districts.

Table 5. Correlation between Total Members of Muhammadiyah and Development of Total Area of Muhammadiyah Heritage in Three Districts.

\begin{tabular}{llll}
\hline & Large & Member \\
\hline Large & Pearson Corelation & 1 &, $709(* *)$ \\
& Sig. & 14 &, 005 \\
\multirow{4}{*}{ Member } & $\mathrm{N}$ &, $709(* *)$ & 14 \\
& Pearson Corelation &, 005 & 1 \\
& Sig. & 14 & 14 \\
\hline
\end{tabular}

** Correlation is significant at the 0.01 level

\section{INTERPRETATION OF STATISTICAL DATA ANALYSIS METHOD}

In the arrangement of all of the data, objects amounted to a total of 10 units. All of them use the unit area meter per square (m2). It is used because it is easily calculated and the majority of the building does not have such great extents.

In data presentation of histogram, polygons, and pie-chart, it can be seen that the most dominant is the Madrasah Mu'allimin Muhammadiyah. Seeing these data, it can be interpreted that Muhammadiyah prioritize cadre education to give a fairly spacious room on the first set of the building (1932) until now the land is still survive.

From the size of concentration consisting of the mean, median, modus, and the size of the diversity, it can be known that the average area of the Muhammadiyah heritage in the three districts is $2,407.94 \mathrm{~m} 2$. It declares that Muhammadiyah is already progressive in the organization. The median is $1,588.5 \mathrm{~m} 2$. Median is lack of benefits for research may be just as middle value only results count. Modus in this research is $80 \mathrm{~m} 2$.

It means that an object that appears most frequently is KH. Ahmad Dahlan Mosque because it has a space of $81.4 \mathrm{~m} 2$. It is caused from the beginning of Muhammadiyah (1912) until 1922, there was no heritage found, because the discussion in this paper is the development of a more highlighted the building in South Kauman that most often appear in a statistical count. The variance is $7,901,735.503$. The meaning of these numbers is the relative position of each observation data which is the average of the data group Muhammadiyah heritage. The standard deviation is 2811.0026. 
Last statistical analysis using the correlation method is a way to make a conclusion in the present study. First, heritage of the area development data are presented both in table form and line diagrams. All of them describe that object of this research has increased continuously. At the period between 1912 - 1920, there is stagnation because only KH. Ahmad Dahlan Mosque is found. The need for a place of worship as a means of strengthening the basis of the organization is the reason behind it. In the period between 1920 - 1940, there is a significant increase shown by several objects, such as, 'Aisyiyah Mosque, Muhammadiyah Notoprajan Elementary School, Asri Field Wirobrajan, Madrasah Mu'allimin Muhammadiyah, Madrasah Mu'alimaat Muhammadiyah, and Muhammadiyah 1 Yogyakarta Junior High School founded in that time interval. Historically, it is caused by the need for cadres in this organization.

From the tables and charts, an outline on the development of Muhammadiyah members also continued to raise the same as before and the increase is happening at the interval $1940-1964$. The increase was based on the history due to the awareness of the indigenous to a movement that would indeed have been existing before Boedi Oetomo to argue and gather with the goal of independence and defended by the use weapons. Social and political situation of Indonesia at that time also affects the modest increase. The entire line diagram above has increased in tune with each other and is indicating a correlation. Strengthen data can be seen in diagram 3 which is correlation between the two variables. The first is the development of the area number of Muhammadiyah Heritage in Gondomanan District, Ngampilan District, and Wirobrajan District in Yogyakarta. In addition, the second variable is development of the number of members in the three districts.

To ensure the correlation, before the conclusions declared, it can be submitted two hypotheses to be tested. These are:

- H0: There is no relationship between the development of Muhammadiyah with a quantity of heritage in Gondomanan District, Ngampilan District, and Wirobrajan District in 1912 - 1964.

- H1: There is a relationship between the development of Muhammadiyah with a quantity of heritage in Gondomanan District, Ngampilan District, and Wirobrajan District at 1912 - 1964.

The principle of correlation is if

Pearson Correlation $(\mathrm{r})>0.5$, so reject $\mathrm{H} 0$

Pearson Correlation (r) <0.5, so accept H0 (Hartono, 2010, 57-59).

Due to the output numbers $\mathrm{r}=0.709$ then the result is reject $\mathrm{H} 0$ or accept $\mathrm{H} 1$ to the implications that there is relationship between Muhammadiyah development with the quantity of the heritage at Gondomanan District, Ngampilan District, and the Wirobrajan District Yogyakarta in 1912 - 1964.

The next way is a coefficient at 0.709 is greater than 0.532 at significance level of $5 \%$ and 0.709 $>0.661$ at significant level of $1 \%$.

$$
\begin{aligned}
\mathrm{df} & =\mathrm{N}-\mathrm{nr} \\
& =14-2 \\
& =12 \text { (in table } \mathrm{r} \text { product moment) }
\end{aligned}
$$

Thus H0 is rejected, which means there is a significant correlation. In addition, there are the other alternate requirements that when the correlation coefficient or the notation " $r$ " is getting closer to 1 or -1 so among the two variables have a close relationship / strong / high. Due to the resulting output on Pearson Correlation or $r=0.709$ (close to 1) with the addition of an identifier ** which shows a significant correlation between the two variables which the conclusion, there is a strong relationship / close / significant / positive.

\section{Conclusion}

The parameters in this research are the data obtained from the PDM Yogyakarta which indicates that the object coming from the heritage of the three districts above reached 10 units. It means the parameter population is 10 . From the results of the analysis can be concluded that the most dominant heritage is the Madrasah Mu'allimin Muhammadiyah. It proves that Muhammadiyah very concerned about the pioneering educational aspect. 
Statistical analysis that can answer the problems of this research is using correlation method. Tables and charts of development Muhammadiyah members and the development of an area of heritage shown that there is correlation by the increase between them. Result output correlation method implies that there is a relationship between the development of Muhammadiyah with a quantity of heritage in Gondomanan District, Ngampilan District and Wirobrajan District Yogyakarta in 1912 - 1964. In conclusion, there is a strong relationship / close / significant / high between the two variables above.

\section{References}

[1] Hartono. (2010). SPSS 16.0 Analisis Data Statistika dan Penelitian. Yogyakarta : Penerbit Pustaka Pelajar.

[2] Kazmier, Leonard J. (2004). Schaum's Easy Outlines Business Statistics. Jakarta : Penerbit Erlangga.

[3] Kotz, Samuel (ed.). (2005). "Parameter". In "Encyclopedia Of Statistical S Sciences". Vol. 9. Washington : A John Wiley \& Sons, Inc., Publication.

[4] Santoso, Slamet. (2009). Statistika Induktif. Yogyakarta: Ardana Media.

[5] Saputra, Roni. (2013). Statistik Terapan dalam Ilmu Kesehatan Masyarakat. Padang: Program Studi DIV Analis Kesehatan Stikes Perintis Sumbar.

[6] Shennan, S. (1988). Quantifying Archaeology. Edinburgh: Edinburgh University Press.

[7] Sugiyono. (2013). Statistika untuk Penelitian. Bandung : Alfabeta.

[8] Suhartono, Uray. (2015). Statistik Prasarana dan Sarana Pertanian Tahun 2011 - 2015. Jakarta: Dirjen Sarpras Pertanian Kementan RI.

[9] Supriyadi, Bambang. (2015). Kopertis Wilayah V dalam Angka Tahun 2015. Yogyakarta: Ristekdikti.

[10] Walpole, R. E. (1997). Pengantar Statistika. Jakarta: Penerbit PT. Gramedia Pustaka Utama. 